\title{
Quality of death counts and adult mortality registration in Suriname and its main regions
}

\author{
Andrea Fernand Jubithana* \\ Bernardo Lanza Queiroz ${ }^{* *}$
}

Suriname statistical office assumes that mortality data in the country is of good quality and does not perform any test before producing life table estimates. However, lack of data quality is a concern in the less developed areas of the world. The primary objective of this article is to evaluate the quality of death counts registration in the country and its main regions from 2004 to 2012 and to produce estimates of adult mortality by sex. We use data from population, by age and sex, from the last censuses and death counts from the Statistical office. We use traditional demographic methods to perform the analysis. We find that the quality of the death count registration in Suriname and its central regions is reasonably good. We also find that population data can be considered good. The results reveal a small difference in the completeness for males and females and that for the sub-national population the choice of method has implication on the results. To sum up, data quality in Suriname is better than in most countries in the region, but there are considerable regional differences as observed in other locations.

Keywords: Suriname. Vital records. Data quality. Mortality estimates. Death distribution methods.

\footnotetext{
* Anton de Kom Universiteit van Suriname (AdeKUS), Paramaribo, Suriname (andrea.jubithana-fernand@uvs.edu; https:// orcid.org./0000-0001-8377-9838).

** Universidade Federal de Minas Gerais (UFMG), Belo Horizonte-MG, Brazil (lanza@cedeplar.ufmg.br; https://orcid. org./0000-0002-2890-1025).
} 


\section{Introduction}

Estimates of life expectancy and adult mortality in many less developed countries, such as Suriname, are not yet accurate because of the poor quality of data collected and/or due to the lack of adequate civil records. In most of the least developed countries, available data are deficient due to the limited coverage of vital statistics, and even when coverage is good, age information has been found to be inaccurate (LUY, 2010; HILL, 2017). In these countries, given the limited coverage and/or lack of civil records, an alternative to producing adequate demographic estimates, especially mortality and health, has been the application of information from demographic censuses or sample surveys and indirect demographic methods (UNITED NATIONS, 1983, 2002).

The two last censuses (2004 and 2012) and yearly registration of death counts offer an opportunity for evaluating and estimating adult mortality in Suriname and its main regions. Suriname is an interesting option to study due to its small population size, only 542,639 inhabitants in 2012, which might create additional methodological challenges, and to its large social and regional differences. Given that deaths are a very rare event, there are areas of the countries without any event registered for some age groups. This might happen due to the small number of events, but also due to the lack of adequate death registration. There are very few studies on mortality by regions in Suriname, mainly due to the data and methodological limitations. In general, we find estimates of mortality for five-year age groups for some years provided by the General Bureau of Statistics, but no estimates of adult mortality, or a very detailed analysis of data quality. In this paper, we use data from the last two censuses (2004 and 2012) and yearly death counts, by age and sex, from the Bureau of Statistics to evaluate the quality of mortality data in the country and to produce estimates of mortality using formal demographic methods.

The objective of this article is to evaluate the data quality of the death counts and population data and estimate adult mortality in Suriname and its central regions by sex using the Death Distribution Methods (HILL, 2017; HILL; YOU; CHOI, 2009). Although they have some limitations, DDMs provide very robust and consistent results for a series of applications across the globe (PERALTA et al., 2019; WANG et al., 2016; LIMA; QUEIROZ, 2014). One important issue when using DDM for regions is the impact of migration flows. Hill and Queiroz (2010) show this impact and present alternatives to include migration in the models, but their method demands some additional migration data. In order to address this issue, we apply each variation of the methods using age groups that include and exclude most of the migration flows. This exercise is performed to observe the difference in adult mortality estimates in cases when the proportion of high migration (age groups 15-34 or 15-29) is more prevalent and when it is not. Data quality is assessed by analysing the completeness of death registration and demographic measures for data errors. The estimation of adult mortality is conducted using the summary index of adult mortality, probability of dying between 15 and 60 years of age $\left({ }_{45} q_{15}\right)$. 
Suriname is a former colony of the Netherlands and has a civil registration system since 1917. Given the fact that the country has had a functioning population register system in place for one century, the official bureau is expected to produce reasonable to good registration of vital statistics. The Centraal Bureau Voor Burger Zaken (CBB) of the Ministry of Internal Affairs of Suriname is responsible for the yearly registration of vital statistics, such as birth, death, migration and other demographic events. In recent years more bureaus for registration of vital statistics were created in the country, which also helped improve the coverage of the registration of births and deaths.

Suriname is divided into ten districts, sixty two resorts and three central regions: 1 ) urban coastal area; 2) rural coastal area and 3) rural interior area. In this paper, we focus on the three main regions in order to avoid the problem of dealing with very small sub-national populations. However, despite working with the three main regions, the analysis is still limited. The total population in the urban coastal area was 359,146 in the 2012 Census, whereas the rural coastal area and the rural interior area had a total population of 111,224 and 71,268 , respectively. Furthermore, internal and international migration also make this study relevant, since migration also affects the proposed methods.

The paper is also an important methodological exercise in assessing the quality of mortality information in Suriname in recent years. The Surinamese population has undergone important transformations that have been poorly studied and documented, especially due to the low availability of data. In the case of the least developed countries, understanding population mortality and health helps assess social and health progress and identify the effectiveness of government programs as well as locate high-risk groups.

\section{Data and methods}

We use data from the General Bureau of Statistics (GBS) and CBB in Suriname. The population data, by age and sex, is from the 2004 and 2012 Censuses. We use average death counts between 2004-2012, by age and sex and region. The first stage of our analysis is focused on the quality of information by age and sex. For the evaluation of the quality of the death counts and population data, Whipple's Index and the Index Concentration on Single ages (JDANOV et al., 2008) are applied.

In the second stage, we evaluate data quality and estimate mortality using the Death Distribution Methods (HILL, 2017; MURRAY et al., 2010; AGOSTINHO, 2009). Hill, You and Choi (2009) show that the DDM's assess the completeness of death recording relative to census recording. The DDM's are the method of choice for Census data, and for death counts registration by age when available, as they provide age-period precise estimates of mortality (HILL, 2017; MURRAY et al., 2010). Moreover, the DDM's compare the distribution of deaths by age with the age distribution of those who are alive between both censuses. There is a link between the allocation of the population and the distribution of the deceased through the growth rates in different identities which provides a basis for consistency checks (HILL; 
YOU; CHOI, 2009). It is important to highlight that completeness of death counts coverage, in the DDM approach, is relative to intercensus coverage and is not an absolute coverage of death counts registration (HILL, 1987)

There are three strategies for non-stable populations, the General Growth Balance GGB (HILL, 1987), Synthetic Extent Generation - SEG (BENNETH; HORIUCHI, 1981) and the Hybrid GGB-SEG (HILL; YOU; CHOI, 2004). The GGB (HILL, 1987) is derived from the Growth Balance (BRASS, 1975), which is based on the relationship that for any open-ended age segment $a+$ of a closed population, the entry rate into the segment $(b(a+))$ is equal the growth rate of the segment $(r(a+))$ plus the exit death rate $(d(a+))$ of the segment. The GB (BRASS, 1975) can be generalized for the non-stable population when two or more censuses are available. In the case of non-stability, the growth rates for every age segment are obtained from the available censuses (HILL, 1987). The entry rate minus the growth rate estimates the residual death rate. The linear equation (1) derived from the balance equation determines an intercept and a slope.

$\frac{N^{*}(x)}{N(x+)}-r(x+)=\frac{1}{t} \ln \left(\frac{k_{1}}{k_{2}}\right)+\frac{\left(k_{1} * k_{2}\right)^{1 / 2}}{C} * \frac{D^{*}(x)}{N(x+)}$

The intercept $\frac{1}{t} \ln \left(\frac{k_{1}}{k_{2}}\right)$ captures any age invariant change in census coverage between two censuses. In other words, the intercept covers the error in the growth rate, which is assumed to be constant across ages. The slope $\frac{\left(k_{1} * k_{2}\right)^{1 / 2}}{C}$ estimates the coverage of death recording relative to an average of the coverage of the two censuses (HILL, 1987; HILL; YOU; TIMAEUS, 2003; HILL; YOU; CHOI, 2009).

Furthermore, $N(x+)$ is the person-years lived by the population age $x$ and over and it is the geometric mean of the first and second census. In equation (1) $N^{*}(x)$ and $D^{*}(x)$ is the observed population and the intercensal deaths, respectively. In addition, $k_{1}$ and $k_{2}$ are the coverage of the first and second census and $C$ is the completeness of death. The relation $\frac{k_{1}}{k_{2}}$ expresses the coverage of the first Census with respect to the second Census, indicating the coverage differential between both censuses. Thus, the completeness of death register is between two censuses and in this study it is between the 2004 and the 2012 Censuses.

Table 1 presents a more detailed analysis of each parameter and an interpretation of the intercept and slope of the GGB method (HILL, 1987). It also shows possible outcomes when applying the method and their interpretation. 
TABLE 1

Explanation of the intercept and slope of GGB method

\begin{tabular}{|c|c|c|c|c|c|}
\hline \multicolumn{3}{|c|}{ Intercept $=\frac{1}{t} \ln \left(\frac{k_{1}}{k_{2}}\right)$} & \multicolumn{3}{|c|}{ Slope $=K=\frac{\left(k_{1} * k_{2}\right)^{1 / 2}}{C}$} \\
\hline Positive & Negative & Zero & $0<K \ll 1$ & $K=1$ & $K \gg 1$ \\
\hline$k_{1}>k_{2}$ & $k_{1}<k_{2}$ & $k_{1}=k_{2}$ & & & \\
\hline $\begin{array}{l}\text { Coverage first } \\
\text { Census better } \\
\text { second Census }\end{array}$ & $\begin{array}{l}\text { Coverage second } \\
\text { Census better } \\
\text { than first Census }\end{array}$ & $\begin{array}{l}\text { Coverage first } \\
\text { Census is equal } \\
\text { second Census }\end{array}$ & $\begin{array}{l}\text { Under - } \\
\text { registration of } \\
\text { deaths regarding } \\
\text { population }\end{array}$ & $\begin{array}{l}\text { Completeness } \\
\text { of population } \\
\text { recording } \\
\text { relative to death } \\
\text { recording }\end{array}$ & $\begin{array}{l}\text { Over registration } \\
\text { of deaths } \\
\text { regarding the } \\
\text { population }\end{array}$ \\
\hline
\end{tabular}

Source: Own elaboration based on GGB methodology (HILL, 1987).

The second method used in this study is the Synthetic Extinct Generations (SEG) method proposed by Bennett and Horiuchi $(1981,1984)$ and based on the insight of Vincent (1951). The method relies on the fact that in a closed population, the reporting of death is good and the population age $a$ at time $t$ could be estimated by accumulating deaths to that cohort after time $t$ until the cohort was extinct. Benneth and Horiuchi generalized the method to non-stable closed populations by using age-specific growth rates to convert the distribution of deaths by age to the allocation of the population. The formula from Benneth and Horiuchi is presented in equation (2).

$\hat{N}(a)=\int_{x=a}^{\bar{w}} D(x) e^{\int_{a}^{x} r(y d y)} d x$

In equation (2) the population $\hat{N}(a)$ at age $a$ is estimated at the period deaths at all ages $x,(D(x))$ above age $a$ by using the exponential summing age-specific growth rates from $a$ to $x$. The calculation of the coverage of deaths above age $a$ compared with the population, $c(a)$ is given by the ratio of $\hat{N}(a)$ to the observed population at age $a, N(a)$.

Finally, the hybrid method of GGB and SEG suggested by HILL et al. (2009) is applied in this study. This third method consists of using first the GGB method to estimate the change in census coverage $\frac{k_{1}}{k_{2}}$ and then use this estimate to correct the data of one of the two censuses. Finally, the SEG method is applied in the GGB-SEG method using the adjusted census population to obtain the level of coverage of the mortality data. Since there is no gold standard regarding which method to apply, it is useful to apply a combination of them and analyze the estimates (HILL; YOU; CHOI, 2009; AGOSTINHO, 2009; PERALTA et al., 2019).

We follow the same procedure in this paper, using combinations of age segments and methods to obtain more robust estimates for the country and regions. It is important to use different age segments, because it becomes possible to observe: 1) the effects of the presence of high peak migration; 2) the differences between short/ long age segments; and 3) partially take out the effect of migration. In case a population experiences positive or negative migration flows and the volume of the population is small, it is advisable to use age segments without high proportion of peak migration (HILL; QUEIROZ, 2010). The use of age segments with high proportion of peak migration is encouraged for populations 
with zero net migration. Age segments with high proportion of peak migration ( $5+$ to $65+$, $15+$ to $55+, 15+$ to $75+)$ and without high proportion of peak migration $(30+$ to $65+, 30+$ to $55+, 30+$ to $60+, 35+$ to $60+, 30+$ to $75+$ ) are chosen for the application of the DDM's to obtain probabilities of dying by different methods and age segments. The reason to make use of the two clusters of age segments is because Suriname is characterized by positive and negative international and internal migration (ZLOTNIK, 2004). Suriname is one of the countries with a net migration as percentage of natural increase of -57 , a net number of migrants of -182000 and a net migration rate of $-1.45 \%$. The natural increase was $2.54 \%$. Furthermore, Suriname is also a country with statistical outliers by rate of net migration rates $(-1.45)$. The results by different DDM's and age segments make it possible to observe the partial effect of the violation of no-migration assumption. The use of different age segments and methods also allows to observe which of the age segments results in better fitness.

The adequate way to analyse the quality of DDM estimates is to study the diagnostic plots of the GGB, SEG and GGB-SEG (HILL, 2001; HILL; CHOI; TIMAEUS, 2005). The plots allow us to observe the violation of the assumptions for the application of the methods. Furthermore, the diagnostic plots show the completeness of death register and the quality of the death count data (HILL, 2017; QUEIROZ et al., 2017).

For the diagnostic plot of the GGB method, the horizontal scale represents the observed death rate, $a+$ and the vertical scale represents the difference between the entry rate $a+$ and the growth rate $a+$ (HILL, 2001; CHOI; TIMAEUS, 2005). For the diagnostic plots of the SEG and the GGB-SEG methods, the vertical scale represents completeness of death recording for age $a+$ and the horizontal scale represents age segment $a+$ (HILL, 2001; CHOI; TIMAEUS, 2005).

In this paper, the diagnostic plots of GGB ( $5+$ to $65+$ ), SEG method and GGB-SEG for age segment $5+$ to $65+$ and $30+$ to $60+$ will be presented for the female population of Suriname. This exercise will be done in order to observe the violation of the assumptions by methods and mainly the no-migration assumption in the event of presence or absence of high proportion of migration. We performed a similar evaluation for all age ranges, but due to space limitations, we only show one specific example.

\section{Results}

First, we present estimates of data quality using Index Concentration on Single Ages for males and females for population (Census 2004 and 2012) and death counts data (average 2004-2012) of Suriname. Later, we show the estimates of the completeness of death registration using alternative methods and age segments. Finally, we present and discuss the estimates of adult mortality. 


\section{Data quality considering Whipple index}

Table 2 presents the results of the Whipple's Index for the population data of Suriname and its regions. The data quality for the male and female population is considered to be good for the population of Suriname and its main regions applying the measures proposed in this article. Values below 105 for the Whipple's Index indicate that data can be considered precise (UNITED NATIONS, 1955).

TABLE 2

Whipple's index for population data Census 2004 and 2012 of Suriname and its central regions

\begin{tabular}{lrccrrrrr}
\hline \multirow{2}{*}{ Regions } & \multicolumn{3}{c}{ 2004 Census } & & \multicolumn{3}{c}{ 2012 Census } \\
\cline { 2 - 3 } & Male & Female & Total & & Male & Female & Total \\
\hline Suriname & 100.4 & 102 & & & 101.76 & 101.72 & \\
Urban coastal & 101.35 & 103.47 & 102.42 & & 101.72 & 102.64 & 102.19 \\
Rural coastal & 95.65 & 99.47 & 97.43 & & 100.86 & 99.28 & 100.12 \\
Rural interior & 103.68 & 96.33 & 99.98 & & 103.98 & 100.30 & 102.08 \\
\hline
\end{tabular}

Source: GBS 2004 and 2012 Censuses.

The results of the death count registration data applying the Whipple's index for the main areas can be seen in Jubithana (2016). The death count data using Whipple's Index is less precise $(105-110)$ or precise ( $(105)$ depending on the region and age group. Considering age group 23-62 we observe that for male population of the urban coastal area, the rural coastal area and the rural interior area the Whipple index (digit 0 and 5) of death count data is, 100, 90 and 108 respectively. Considering the Whipple index (digit 0 and 5) of the death count data for the female population, for age group 23-62 we find the values of 102, 102, 86 for the urban coastal area, rural coastal area and rural interior area respectively. As can be observed for the male population in the rural interior, the Whipple index of death count data is equal to 108 , which indicates that the data is less precise. For the female population in the rural interior area, it can be observed that the Whipple index is very low, namely 86 and categorized as precise. The rural interior area is the main region in Suriname with legal and illegal gold mining and work in this economic sector involves the male population. In the illegal gold mining sector it may occur that not all death events are registered. With respect to Internal Migration in the rural interior area there is a negative net migration for both sexes for age groups 5-9 to 35-39. Moreover, the rural interior area has the lowest Human Development Index, 0.599 (HAD, 2013). It is also the area where some locations are only accessible by boat or airplane and registration of death count data is not done on time, due to the fact that the registration bureaus are not close to the places or residence. The rural interior area, with $87 \%$ of the country's surface, had a population density of 0.50 in the 2012 Census. The greatest part of the country is covered by approximately $80 \%$ of pristine rainforest. 


\section{Data quality considering index concentration in single ages}

Data quality of the 2004 Census population for all the main regions for male and female population considering the index concentration in single ages ending in " 0 " and " 5 ", show no preferences until 75 years of age. Female population in the urban coastal area shows preferences for ages 80 and 90, with values 110.44 and 108.18, respectively. However, male population for age 90 shows a significant preference in the urban coastal area with a value of 213.74 , which is considered to be high.

For the main regions, the data for male population of the rural interior area in the 2012 Census show higher preferences in adult, mature and old ages (40, 55, 70, 80 and 90 years old), compared to the other regions. For male and female population in the rural coastal area, the index concentration in single ages for age 90 can be considered high, 161.63 and 158.75 respectively. The male population of the rural interior area shows the highest value (205. 59) for age 90 of the index concentration in single ages in the 2012 Census. To sum up, the rural interior shows preferences in older ages, but also in mature and adult ages. The rural coastal area also shows preferences in age 90 , for male and female population.

Considering death count data for Suriname, we can see that the ICSI for male and female population (2009-2012) fluctuates more than the ICSI of both sexes (2006-2012). The ICSI values for female population are high in ages 15 and 30,161.99 and 155.34 respectively. For male population, the ISCI for death count data is high for age 10 , namely 139.24 . The lowest ISCI values for male and female are observed in adolescents and children, amounting to 53.6 and 40.26 respectively. For ages 40 and above fluctuations for male and female population are less strong. The extremely low ISCI values probably indicate a very small number of death events, or no such events.

Due to the small scale of death count data in the main regions, the ICSI shows more fluctuations for these areas in comparison to ICSI values at national level. With regard to death count data for the main regions, the number of deaths is smaller or rarer in some age groups than in Suriname and therefore, fluctuations are more visible in the main regions. The male population of the main regions shows less fluctuation of ISCI for death count data compared to the female population of the main regions. For the male population of the urban coastal area, the ICSI is only high for age 10 at 161.88 . For the other ages, ICSI values are very close to 100 in the urban coastal area. The rural interior area shows the highest values for male population in ages 25, 40, 50 and 75 . Age 25 has the highest ICSI value, at 209.15. The rural coastal area shows less fluctuation for the male population and the highest ICSI values are in ages 20, 30, 40 and 70. The highest value is in age 20 and it is 142.7.

Considering female population of the urban coastal area, ISCI fluctuations are present for ages under 40 and the highest value is for age 15, at 160.42. For ages 40 and above, $\mathrm{ISCI}$ values for female population in the urban coastal area are very close to 100 . For the rural coastal area, ISCI values for female population is increasing from age 5 to age 40 and then the ISCI values fluctuates. The highest ISCI value in the rural coastal area is for 
age 40, at 155.16. In the rural interior area, ISCI values for female population show strong fluctuations for the age range 5-90. As expected, there are ISCI values of zero in the three main regions. However, these values are only observed for female population. For the urban coastal area, the zero value is for age 10 , whereas for the rural coastal area the zero value is for age 5, and for the rural interior area it is for age 60 .

In the ICSI formula, the logarithm of number of deaths in the denominator is taken for two ages, inferior and superior, to the age in the numerator. In our study, ages in the numerator end in zero or five. When there are no deaths, it is not possible to take the logarithm, and as a result the ICSI becomes smaller, resulting in ICSI fluctuations. Despite the above, the zero values of $\mathrm{ISCl}$ appear because there are zero deaths in a specific age ending in zero or five.

\section{Estimation of the completeness of death counts for Suriname}

The results of the completeness of death counts registration are presented for the GGB, SEG and GGB-SEG method by different age segments, considering or omitting peak migration for Suriname. Table 3 presents the results for females and Table 4 for males. Completeness of death counts registration when using age segments with a high proportion of peak migration presents higher values for the GGB method in relation to the SEG and the GGB-SEG methods. However, the age segments without a significant proportion of peak migration present, for the GGB and SEG methods, very similar values of completeness of death registration and values above the unity, as discussed in other papers (HILL; QUEIROZ, 2010).

In some cases, the completeness of death register above one unity reveals that the registration of deaths regarding the population is more than complete, thus overestimating mortality. In the case of values above the unity, migration may be a possible explanation for the small-scale population, as well as the existence of age varying of census coverage change, and the fact that death counts registration have better quality than population registration (HILL, 1987; HILL; YOU; CHOI, 2009).

Hill, You and Choi (2009) argue that the SEG method is more sensitive to migration and the GGB method is sensitive to age misreporting and age varying of census coverage change. SEG method tends to underestimate death coverage and overestimate mortality in case of emigration. The GGB-SEG method presents values below the unity for age segments without a high proportion of peak migration indicating that the death register corresponding to the population is not complete. For age segment $30+$ to $65+$, the completeness of death register for the female population is $98 \%$ applying the GGB-SEG method and for the male population there is the completeness of death record (100\%). In general, the results indicate that the quality of census data and death counts registration is good. Estimates indicate that both censuses have very similar levels of coverage, for both males and females, and that the death counts registration system for the country presents good quality, especially when compared to other countries in Latin America (PISCOYA; QUEIROZ, 2010; LIMA; QUEIROZ, 2014; PERALTA et al., 2019). 
TABLE 3

Completeness of death counts registration, females - 2004-2012

\begin{tabular}{|c|c|c|c|c|}
\hline \multicolumn{3}{|c|}{ GGB method } & SEG method & GGB-SEG method \\
\hline \multirow[b]{2}{*}{$\begin{array}{l}\text { Age segments } \\
\text { including high } \\
\text { net migration }\end{array}$} & \multirow{2}{*}{$\begin{array}{c}\text { Census } \\
\text { coverage } \\
\text { change: } 2012 \\
\text { to census } 2004\end{array}$} & \multirow{2}{*}{$\begin{array}{l}\text { Completeness of } \\
\text { death registration } \\
\text { relative to } \\
\text { population }(1 / \mathrm{K})=\mathrm{C}\end{array}$} & \multicolumn{2}{|c|}{$\begin{array}{l}\text { SEG method completeness of death } \\
\text { registration relative to population }\end{array}$} \\
\hline & & & $\begin{array}{l}\text { Unadjusted for } \\
\text { census coverage } \\
\text { change }\end{array}$ & $\begin{array}{c}\text { Adjusted for census } \\
\text { coverage change } \\
\text { (according to age } \\
\text { segment) }\end{array}$ \\
\hline $15+$ to $55+$ & 0.9937 & 1.1821 & 1.0981 & 1.0585 \\
\hline $5+$ to $65+$ & 0.9964 & 1.1747 & 1.0813 & 1.0752 \\
\hline $15+$ to $75+$ & 0.9842 & 1.0892 & 1.0783 & 1.0585 \\
\hline \multicolumn{5}{|l|}{$\begin{array}{l}\text { Age segments } \\
\text { excluding high } \\
\text { net migration }\end{array}$} \\
\hline $30+$ to $65+$ & 0.9808 & 1.0966 & 1.0929 & 0.9800 \\
\hline $30+$ to $75+$ & 0.9756 & 1.0649 & 1.0764 & 0.9532 \\
\hline $35+$ to $75+$ & 0.9712 & 1.0504 & 1.0722 & 0.9283 \\
\hline $30+$ to $60+$ & 0.9817 & 1.1043 & 1.1000 & 0.9874 \\
\hline $35+$ to $65+$ & 0.9775 & 1.0822 & 1.0899 & 0.9638 \\
\hline
\end{tabular}

Source: GBS, 2004 and 2012 Censuses and CBB 2004-2012.

TABLE 4

Completeness of death counts registration, males - 2004-2012

\begin{tabular}{|c|c|c|c|c|}
\hline \multicolumn{3}{|c|}{ GGB method } & SEG method & GGB-SEG method \\
\hline \multirow{2}{*}{$\begin{array}{l}\text { Age segments } \\
\text { including high } \\
\text { net migration }\end{array}$} & \multirow{2}{*}{$\begin{array}{l}\text { Census } \\
\text { coverage } \\
\text { change: } \\
2012 \text { to } \\
\text { census } 2004\end{array}$} & \multirow{2}{*}{$\begin{array}{l}\text { Completeness of } \\
\text { death registration } \\
\text { relative to } \\
\text { population } \\
(1 / \mathrm{K})=\mathrm{C}\end{array}$} & \multicolumn{2}{|c|}{$\begin{array}{c}\text { Completeness of death registration relative to } \\
\text { population }\end{array}$} \\
\hline & & & $\begin{array}{l}\text { Unadjusted for } \\
\text { census coverage } \\
\text { change }\end{array}$ & $\begin{array}{c}\text { Adjusted for census } \\
\text { coverage change (according } \\
\text { to age segment) }\end{array}$ \\
\hline $15+$ to $55+$ & 1.0220 & 1.2139 & 1.0824 & 1.2137 \\
\hline $5+$ to $65+$ & 1.0128 & 1.3635 & 1.0793 & 1.1571 \\
\hline $15+$ to $75+$ & 0.9861 & 1.0484 & 1.0658 & 1.0068 \\
\hline \multicolumn{5}{|l|}{$\begin{array}{l}\text { Age segments } \\
\text { excluding high } \\
\text { net migration }\end{array}$} \\
\hline $30+$ to $65+$ & 0.9861 & 1.1064 & 1.1021 & 1.0068 \\
\hline $30+$ to $75+$ & 0.9666 & 1.0073 & 1.0800 & 0.9089 \\
\hline $35+$ to $75+$ & 0.9600 & 0.9943 & 1.0776 & 0.8780 \\
\hline $30+$ to $60+$ & 0.9740 & 1.2008 & 1.1113 & 0.9449 \\
\hline $35+$ to $65+$ & 0.9801 & 1.0855 & 1.1022 & 0.9758 \\
\hline
\end{tabular}

Source: GBS, 2004 and 2012 Censuses and CBB 2004-2012.

The diagnostic plot GGB method by age segment $5+$ to $65+$ of the female population for Suriname (Figure 1) reveals that the observed values provide a reasonable to good fit to the fitted values. However, for the young ages, age misreporting or census coverage change may indicate that the observed values are above the fitted values. The fitted values are above the observed values for the young adult ages, probably showing the violation of the no migration assumption and/or the occurrence of census coverage change. The 
diagnostic plot shows the existence of data errors, but it is not possible to know what the levels of the data errors are.

FIGURE 1

Diagnostic plot GGB method by age segment 5+ to 65+ for female population Suriname - 2004-2012

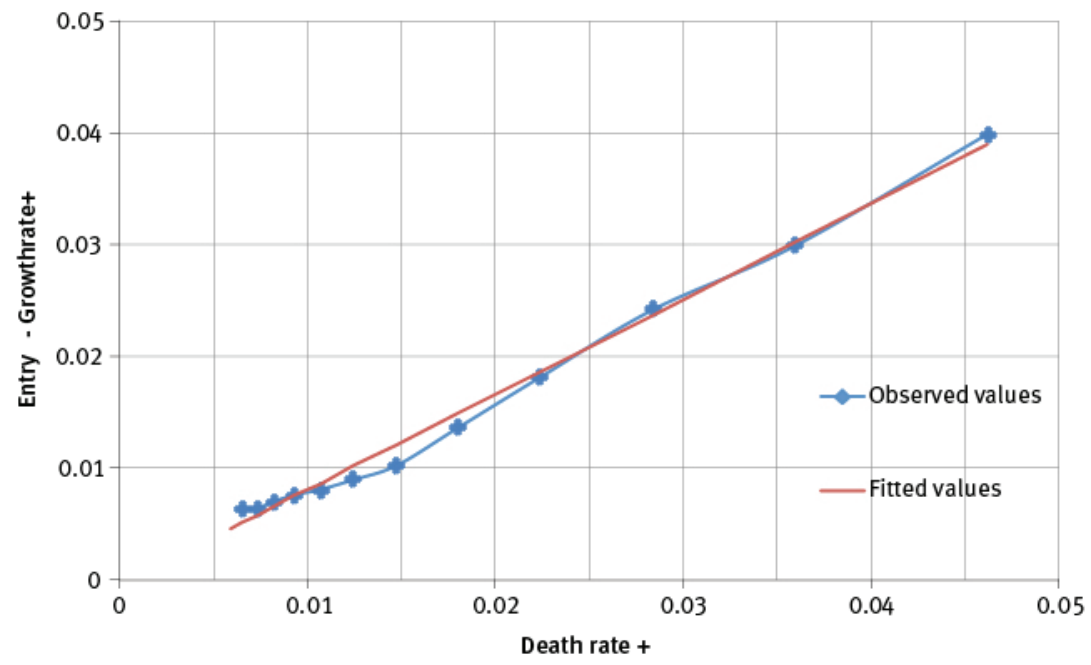

Source: GBS, 2004 and 2012 Censuses and CBB 2004-2012.

Figure 2 shows the diagnostic plot of the SEG method and the GGB-SEG plot for the age segments $5+$ to $65+$ and $30+$ to $65+$ for the female population of Suriname. As can be observed, the diagnostic plot SEG and GGB-SEG age segment indicates over registration of death for all ages above 10 and up to 75+. For the GGB-SEG age segment 30+ to 65+, the completeness of death registration of the population presents some constancy and completeness for ages 30 and over up to age 70 and over. For ages $75+$ and over, the completeness of death registration is observed at 0.98 and 0.71 , and for ages below 30 , the completeness of death registration of the population is 0.84 to 0.96 .

As in the simulation exercise of Hill, You and Choi (2009), values of c(a) greater than the one applying SEG and GGB-SEG indicate age varying of census coverage and possible emigration occurrence. Values below the unity using SEG also indicate the presence of emigration. In the case of the GGB-SEG age segment $30+$ to $65+$, the 2004 Census is corrected with the factor $k_{1} / k_{2}$ of the used GGB method (age segment $30+$ to $65+$ ). After the correction of the 2004 Census data, the SEG method is used. The GGB-SEG plot age segment 30 + to 65 + shows fewer data errors compared to the SEG plot and GGB-SEG plot age segment $5+$ to $65+$. 
FIGURE 2

Diagnostic plot GGB method by age segment $5+$ to $65+$ and $30+$ to $65+$ for female population Suriname 2004-2012

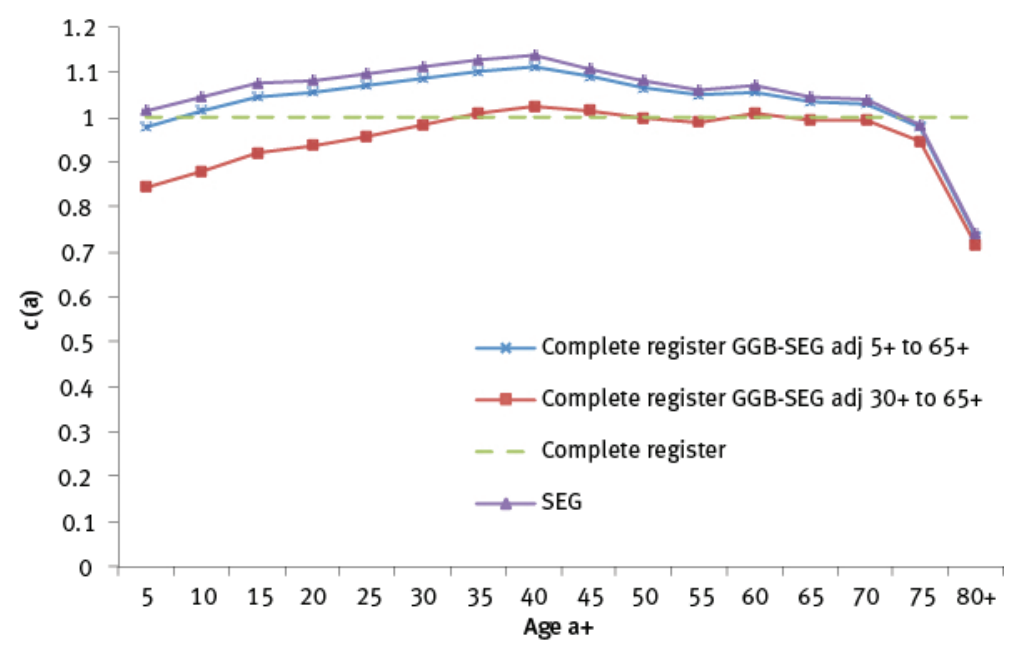

Source: GBS, 2004 and 2012 Censuses and CBB 2004-2012.

\section{Estimation of the completeness of death register for main regions of Suriname}

Table 5 presents the results for the death counts registration for the female population by age segments without peak migration for the main regions. The results with and without peak migration for the male population and with peak migration for the female population can be found in Jubithana (2016). We also observed, for the urban coastal area and rural coastal area, that the results of the estimate of death recording relative to the population applying the SEG method are values above the unity. However, for the rural interior area, the values of the completeness death recording compared to the population are below the unity applying the GGB, SEG, and the GGB-SEG methods. The GGB-SEG methods show the lowest values of the completeness of death recording compared to the GGB and the SEG method. These results reflect the violation of the assumptions by age segment and applied method. A possible explanation for the lower values of completeness of death recording regarding the population using the GGB-SEG method may be the lower sensitivity to age misreporting compared to GGB and the much better performance than SEG with a change in census coverage or migration. It is important to mention that the population and death count data by sex is of very small scale in the rural interior area, thus affecting the results beyond the violation of the assumption of the methods (SCHMERTMANN; GONZAGA, 2018; LIMA; QUEIROZ, 2014). 
TABLE 5

Completeness of death counts registration, females, by region - 2004-2012

\begin{tabular}{|c|c|c|c|c|}
\hline \multicolumn{5}{|c|}{ Female population Suriname } \\
\hline \multicolumn{3}{|c|}{ GGB method } & SEG method & GGB-SEG method \\
\hline \multirow{2}{*}{$\begin{array}{l}\text { Age segments } \\
\text { excluding } \\
\text { high net } \\
\text { migration }\end{array}$} & \multirow{2}{*}{$\begin{array}{c}\text { Census } \\
\text { coverage } \\
\text { change: } \\
\text { Census } 2012 \text { to } \\
\text { Census } 2004\end{array}$} & \multirow{2}{*}{$\begin{array}{l}\text { Completeness of } \\
\text { death registration } \\
\text { relative to } \\
\text { population } \\
(1 / \mathrm{K})=\mathrm{C}\end{array}$} & \multicolumn{2}{|c|}{$\begin{array}{l}\text { Completeness of death registration relative } \\
\text { to population }\end{array}$} \\
\hline & & & $\begin{array}{c}\text { Unadjusted for } \\
\text { census coverage } \\
\text { change }\end{array}$ & $\begin{array}{c}\text { Adjusted for census } \\
\text { coverage change } \\
\text { (according to age segment) }\end{array}$ \\
\hline \multicolumn{5}{|l|}{ Urban coastal } \\
\hline $\begin{array}{l}30+\text { to } 65+ \\
30+\text { to } 75+ \\
35+\text { to } 75+ \\
30+\text { to } 60+ \\
35+\text { to } 65+\end{array}$ & $\begin{array}{l}0.9917 \\
0.9833 \\
0.9796 \\
0.9928 \\
0.9878 \\
\end{array}$ & $\begin{array}{l}1.2652 \\
1.1997 \\
1.1879 \\
1.2774 \\
1.2438 \\
\end{array}$ & $\begin{array}{l}1.1201 \\
1.1875 \\
1.1871 \\
1.2050 \\
1.2024 \\
\end{array}$ & $\begin{array}{l}1.1504 \\
0.9822 \\
0.9617 \\
1.0374 \\
1.0084 \\
\end{array}$ \\
\hline \multicolumn{5}{|l|}{ Rural coastal } \\
\hline $\begin{array}{l}30+\text { to } 65+ \\
30+\text { to } 75+ \\
35+\text { to } 75+ \\
30+\text { to } 60+ \\
35+\text { to } 65+\end{array}$ & $\begin{array}{l}0.9407 \\
0.9404 \\
0.9411 \\
0.9350 \\
0.9423\end{array}$ & $\begin{array}{l}0.8570 \\
0.8605 \\
0.8617 \\
0.8283 \\
0.8611 \\
\end{array}$ & $\begin{array}{l}1.0726 \\
1.0478 \\
1.0292 \\
1.0860 \\
1.0522 \\
\end{array}$ & $\begin{array}{l}0.8004 \\
0.8179 \\
0.8213 \\
0.7923 \\
0.8267\end{array}$ \\
\hline \multicolumn{5}{|l|}{ Rural interior } \\
\hline $\begin{array}{l}30+\text { to } 65+ \\
30+\text { to } 75+ \\
35+\text { to } 75+ \\
30+\text { to } 60+ \\
35+\text { to } 65+\end{array}$ & $\begin{array}{l}0.9808 \\
0.9807 \\
0.9758 \\
0.9941 \\
0.9715 \\
\end{array}$ & $\begin{array}{l}0.8011 \\
0.7969 \\
0.7871 \\
0.8884 \\
0.7718 \\
\end{array}$ & $\begin{array}{l}0.8151 \\
0.8033 \\
0.8028 \\
0.8266 \\
0.8199 \\
\end{array}$ & $\begin{array}{l}0.6967 \\
0.6020 \\
0.5858 \\
0.6486 \\
0.5719 \\
\end{array}$ \\
\hline
\end{tabular}

Source: Data CBB and GBS.

\section{Adult mortality for Suriname and its central regions}

We will now analyze adult mortality by region and sex, based on the analysis developed before. The probability of dying from age 15 to $60\left({ }_{45} q_{15}\right)$ is one of the summary indexes to measure adult mortality (HILL; YOU; CHOI, 2009; HILL; TIMAEUS; CHOI, 2005). According to Timaeus (1991) measures of adult mortality reveal the health status and social development of the country or region.

Table 6 presents the results of the average ${ }_{45} q_{15}$ for a male and female population of Suriname and the central regions for age segments with and without a high proportion of peak migration. Considering the results of the average ${ }_{45} q_{15}$ for age segments without high proportion of peak migration, we observe that the urban coastal area has the lowest value of ${ }_{45} q_{15}$ for female population (0.1243).

The rural coastal area presents the highest average of ${ }_{45} q_{15}$ for female population (0.1430), which may probably be attributed to lifestyle and access to health services. For the male population, the average results of ${ }_{45} q_{15}$ are different. The highest average male ${ }_{45} q_{15}(0.2258)$ is in the urban coastal area, which may partially be attributed to external deaths and lifestyle. The lowest average male ${ }_{45} q_{15}(0.1720)$ is in the rural interior area and can probably be explained by male outmigration from the small scale population of the rural interior area. 
TABLE 6

Average probabilities of dying between 15 and 60 years of age for Suriname and central regions - 2004-2012

\begin{tabular}{|c|c|c|c|c|c|c|c|c|}
\hline \multirow[t]{2}{*}{ Sex } & $\begin{array}{l}\text { Urban } \\
\text { Coastal }\end{array}$ & $\begin{array}{c}\text { Rural } \\
\text { Coastal }\end{array}$ & $\begin{array}{c}\text { Rural } \\
\text { Interior }\end{array}$ & Suriname & \multirow{2}{*}{$\begin{array}{c}\begin{array}{c}\text { Urban } \\
\text { Coastal }\end{array} \\
\text { With }\end{array}$} & \multirow{2}{*}{$\begin{array}{c}\begin{array}{c}\text { Rural } \\
\text { Coastal }\end{array} \\
\text { High Prop }\end{array}$} & $\begin{array}{c}\text { Rural } \\
\text { Interior }\end{array}$ & Suriname \\
\hline & Without & High Prop & \multicolumn{2}{|c|}{ Migration } & & & \multicolumn{2}{|c|}{ Migration } \\
\hline Male & 0.2258 & 0.2172 & 0.1720 & 0.2221 & 0.2199 & 0.2100 & 0.1670 & 0.2140 \\
\hline Female & 0.1243 & 0.1430 & 0.1296 & 0.1273 & 0.1220 & 0.1394 & 0.1217 & 0.1235 \\
\hline
\end{tabular}

Source: GBS (2004 and 2012 Censuses) and CBB (2004-2012).

For all regions, the averages of ${ }_{45} q_{15}$ for the male and female population are higher for age segments without a significant proportion of peak migration. The averages ${ }_{45} q_{15}$ are for male and female population of Suriname between the levels of averages ${ }_{45} q_{15}$ of the urban coastal and rural coastal area. It is remarkable that the averages ${ }_{45} q_{15}$ for male and female population of the rural interior area present values lower than in the rural costal area, which can be considered to have better socio-economic development than the rural interior area. This result can be due to the small scale of the rural interior area, as well as to the presence of out-migration and census coverage change. Furthermore, in the rural interior area, average male ${ }_{45} q_{15}$ is about 1.33 times average female ${ }_{45} q_{15}$. Finally, average male ${ }_{45} q_{15}$ in Suriname is nearly 1.73 times more than average female ${ }_{45} q_{15}$. For the urban coastal area and the rural coastal area, average male ${ }_{45} q_{15}$ to average female ${ }_{45} q_{15}$ is about 1.80 and 1.50 respectively. Concluding, the distance between male and female is greater in the urban coastal area and smaller in the rural interior area.

Figure 3 present the ${ }_{45} q_{15}$ for the male population of the urban coastal and rural coastal areas by methods and age segments with and without a high proportion of peak migration. As the results indicate, the different methods and age segments produce values below or above the unadjusted ${ }_{45} q_{15}$. Some age segments show more or less dispersed values of ${ }_{45} q_{15}$ among the different methods. The dispersion across methods and by age segments reveals the various forms of violation of the assumptions of the DDM's applied.

FIGURE 3

Scatter-plot of ${ }_{45} q_{15}$ by methods and age segments for the male population of the urban coastal area and rural coastal area of Suriname - 2004-2012
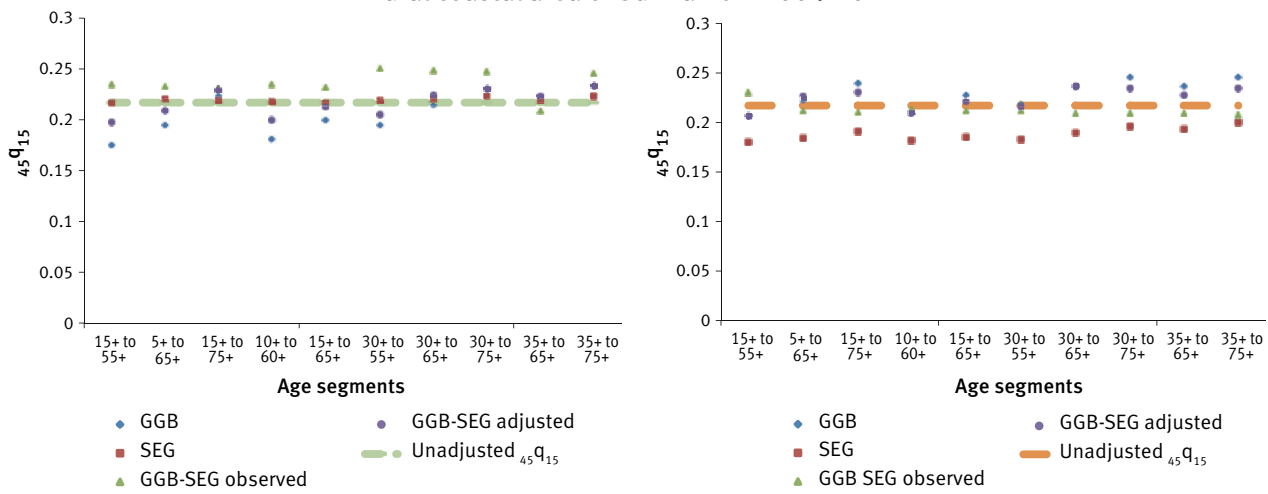

Source: GBS (2004 and 2012 Censuses) and CBB (2004-2012). 
The rural coastal area presents higher ${ }_{45} q_{15}$ applying the GGB method compared to the urban coastal and rural interior area. However, the rural coastal area and the rural interior display the greatest ${ }_{45} q_{15}$ for all three regions by application of adjusted GGB-SEG. The urban coastal zone shows the lowest probabilities compared to the rural coastal area and rural interior area applying the GGB and SEG method. The regional differences of the ${ }_{45} q_{15}$ in Suriname are related to the regions' socio-economic development. The urban coastal area is the most developed area compared to the rural coastal and rural interior areas.

For Suriname, the urban coastal area, and the rural coastal area, the ${ }_{45} q_{15}$ by different methods and age segments are higher for males compared to females. However, for the rural interior area for some age segments and methods, the probabilities of dying between 15 and 60 years of age are higher for females. This outcome for the rural interior area may be related to the sex ratio of the population (100.77) in 2012 due to more male emigration and the small scale of the population in this area. Adequate research may explain the disadvantage of mortality of the female population regarding the male population in the rural interior area using specific methods and age segments.

Moreover, the urban coastal area and the country present similar ${ }_{45} q_{15}$ by method and age segments. For the GGB method, the probabilities of dying between 15 and 60 years of age are the lowest ones for the rural interior area compared to the urban coastal area and rural coastal area for the male and female population for age segments with a high proportion of peak migration. The lower ${ }_{45} q_{15}$ for the rural interior area applying GGB method is probably due to the small scale of the population and the occurrence of age misreporting as well as to the presence of census coverage change.

\section{Conclusion}

In this paper, we evaluated the completeness, quality and internal consistency of the mortality registry in the regions of Suriname from 2004 to 2012. Our results show that the quality of census data and death counts registration for the country present good quality. However, there are inequalities in the registry by sex and geographical area.

The results of the completeness of death registration regarding the population for Suriname for the different methods and age segments are on average above the unity for the male and female population from 2004-2012. For the central regions of Suriname, the values of completeness of death registers depend on the method and age segment applied and are below or above the unity for the male and female population. As is the case in other countries in Latin America and the Caribbean, geographical inequalities in the completeness of death counts registration and adult mortality are not unusual (PERALTA et al., 2019; QUEIROZ et al., 2017). The probabilities of dying between 15 and 60 years of age also show differences by method and age segment for Suriname and its main region. As the country is characterized by internal and international net migration, it would be preferable to make use of DDM's which consider age segments without a high proportion of peak migration to 
diminish the effect of the no- migration assumption. Regarding the violation of the other data errors, it is not possible to isolate their effects. The results obtained in this research require further research on the validation of the methods applied as suggested by Murray et al. (2010). This research is an opportunity to see that the application of the DDM's produce reasonable to good results for a small scale population at a country level with the presence of net international migration, with good quality census data and reasonable to good death count data. According to Dutch Economic historian Coen Van Galen, the government of Suriname has collected information about those who were born, died and got married in Suriname since 1828. Only a few countries in the world, like Suriname, have such good information of population registration that it is possible to follow persons through generations.

The moderate to good results of the application of the DDM's are because the unadjusted ${ }_{45} q_{15}$ are close to the values of the ${ }_{45} q_{15}$ obtained by some DDM's and age segments. For the main regions, rural coastal area and rural interior area, the unadjusted ${ }_{45} q_{15}$ are in some cases less close to the ${ }_{45} q_{15}$ by application of particular DDM's and age segments. Furthermore, the ${ }_{45} q_{15}$ for the female population of Suriname in this research are close to the ${ }_{45} q_{15}$ produced by the United Nations $(0.1350)$ for the period 2005-2010. For the male population of Suriname, the ${ }_{45} q_{15}$ calculated by the United Nations $(0.2401)$ for the period, 2005-2010 are higher than the average results of ${ }_{45} q_{15}$ found in this research.

Studies on other Caribbean countries that could be compared to the specific results from Suriname are scarce. Small scale population and lack of data might explain such absence of studies. The Institute of Health Metrics and Evaluation (IHME) leads the Global Burden of Disease Project and produces estimates of adult mortality and completeness of death counts coverage for a series of countries. In Suriname, they estimate completeness at about $85 \%$ for the same period of analysis in this paper, but we were unable to identify the different methodological approaches used which might explain the differences. Recent studies for other Latin America and Caribbean countries show that quality of mortality data for country level are consistently improving, and that there are large regional differences as well as important differences by gender (PERALTA et al., 2019; QUEIROZ et al., 2017; LIMA; QUEIROZ, 2014; PISCOYA; QUEIROZ, 2010). As other studies for Brazil and Ecuador, we find that data and methods do not perform very well for areas with very small population sizes. An important topic of research and development of methods is how to deal with mortality estimates in such areas. Recent work by Schmmertmann and Gonzaga (2018) developed some alternatives to deal with such areas, but the method is very data demanding. Also, Adair and Lopez (2018) propose an empirical method that demands less information, but which presented some limitation in the case of Ecuador (PERALTA et al., 2019). The results highlight the importance of investing in improving the quality of vital statistics in the country and in different regions within countries. Also, attention should be paid to possible differences across sub-groups of the population such as gender, race/ethnicity. 
Our study has some limitations. The most important ones are related to the limitations of the estimation of completeness obtained by using the Death Distribution Methods (DDMs.) These methods assume that: 1) the studied population is closed to migration or faces very small migration flows; 2 ) that completeness (of mortality and census counts) are constant in all age groups; and 3) that age misreporting is minimal or non-existent. The most important one is related to migration, especially when studying sub-national areas of the country (HILL; QUEIROZ, 2010). As discussed before, Suriname is marked by significant migration flows across regions and to other countries. In order to work with this limitation, we provide a series of estimates using alternative age segments to the DDM applications. The results are fairly robust and consistent for the country.

However, the use of different methods did not yield any surprising result and the problems were close to what previous simulation studies have shown (HILL; YOU; CHOI, 2009; MURRAY et al., 2010). DDMs work quite well when the errors they were supposed to detect are the only data limitations. However, when dealing with sub-national population, we also observed that GGB worked better in some conditions and provided an adjustment to changes in census coverage. SEG was more reliable when dealing with possible changes in age coverage. As suggested by HILL and colleagues and followed here, the combination of GGB and SEG produces more robust results, both at national and local levels.

Our study is the first comprehensive evaluation of the mortality death counts registration in Suriname and of the inequalities (regional and by sex) it entails. The results of this study will be important for public health researchers, planners of national statistics and for the general population. Policy makers in Suriname can use this research to determine which areas and populations require greater attention in order to strengthen and improve the registry and whether the focus should be on completeness, quality, or both.

\section{References}

ABOURZAHAR, C. et al. Civil registration and vital statistics: progress in the data revolution for counting and accountability. Lancet, n. 386, p. 1373-85, 2015.

ABOUZAHR, C.; MIKKELSEN, L.; RAMPATIGE, R.; LOPEZ, A. Mortality statistics: a tool to improve understanding and quality. Brisbane: School of Population Health, The University of Queensland, 2010.

ADAIR, T.; LOPEZ, A. Estimating the completeness of death registration: an empirical method. PLoS One, v. 13, n. 5, e0197047, 2018.

AGOSTINHO, C. S. Estudo sobre a mortalidade adulta, para Brasil entre 1980 e 2000 e Unidades da Federação em 2000: uma aplicação dos métodos de distribuição de mortes. 2009. 243 f. Tese (Doutorado em Demografia) - Centro de Desenvolvimento e Planejamento Regional (Cedeplar), Universidade Federal de Minas Gerais (UFMG), Belo Horizonte, 2009.

BENNETT, N. G.; HORIUCHI, S. Mortality estimation from registered deaths in less developed countries. Demography, v. 21, n. 2, p. 217-234, 1984. 
GBS - General Bureau of Statistics (Suriname). Censuskantoor. Zevende Algemene Volks en Woningtelling in Suriname. Landelijke Resultaten. Volume I. Demografische en Sociale Karakteristieken, Augustus 2005.

GBS - General Bureau of Statistics (Suriname). Censuskantoor. Resultaten Achtste ( $\left.{ }^{e}\right)$ Volks en Woningtelling in Suriname. Volume I. Demografische en Sociale Karakteristieken en Migratie, September 2013.

JUBITHANA, A. Probabilities of dying between 15 and 60 years of age $\left({ }_{45} q_{15}\right)$ in Suriname and its main regions, 2004-2012 - death distribution methods. Ph.D (Dissertation in Demography) Centro de Desenvolvimento e Planejamento Regional (Cedeplar), Universidade Federal de Minas Gerais (UFMG), Belo Horizonte, 2016.

KODAN, L. R. et al. Maternal mortality audit in Suriname between 2010 and 2014, a reproductive age mortality survey. BMC Pregnancy and Childbirth, v. 17, n. 1, p. 1-9, 2017.

HILL, K. Estimating census and death registration completeness. Asian and Pacific Population Forum, v. 1, n. 3, p. 8-13, 1987.

HILL, K. Methods for measuring adult mortality in developing countries: a comparative review. The Global Burden of Disease 2000 in Aging Populations, 2001. (Research Paper, n. 1.13).

HILL, K. Metodos para estimar la mortalidad adulta em los paises en desearollo: uma revision comparativa. Notas de Poblacion, n. 76, p. 81-111, 2003.

HILL, K. Analytical methods to evaluate the completeness and quality of death registration: current state of knowledge. New York: United Nations, 2017. (Technical Paper, n. 2017/2).

HILL, K.; CHOI, Y. Death distribution methods for estimating adult mortality: sensitivity analysis with simulated data errors. In: ADULT MORTALITY IN DEVELOPING COUNTRIES WORKSHOP. Proceedings [...]. Marin County, California: The Marconi Centre, July 2004.

HILL, K.; CHOI, Y.; TIMAEUS, I. Unconventional approaches to mortality estimation. Demographic Research, v. 13, p. 281-300, 2005.

HILL, K.; YOU, D.; CHOI, Y. Death distribution methods for estimating adult mortality: sensitivity analysis with simulated data errors. Demographic Research, v. 21, n. 9, p. 235-253, 2009.

HILL, K.; QUEIROZ, B. Adjusting the general growth balance method for migration. Revista Brasileira de Estudos de População, v. 27, n. 1, p. 7-20, jan./jun. 2010.

LIMA, E. E. C. D.; QUEIROZ, B. L. Evolution of the deaths registry system in Brazil: associations with changes in the mortality profile, under-registration of death counts, and ill-defined causes of death. Cadernos de Saúde Pública, v. 30, n. 8, p. 1721-1730, 2014.

LUY, M. A classification of the nature of mortality data underlying the estimates for the 2004 and 2006 United Nations' world population prospects. Comparative Population Studies, v. 35, n. 2, p. 315-334, 2010.

MATHERS, C. D. et al. Counting the dead and what they died from: an assessment of the global status of cause of death data. Bulletin of the Word Health Organization, v. 83, n. 3, p. 171-179, 2005.

PERALTA, A.; BENACH, J.; BORELL, C.; ESPINEL-FLORES, V.; CASH-GIBSON, V.; QUEIROZ, B. L; MARI-DELL'OLMO, M. Evaluation of the mortality registry in Ecuador (2001-2013) - social and geographical inequalities in completeness and quality. Population Health Metrics, v. 17, n. 1, 2019.

PISCOYA-DÍAZ, M.; QUEIROZ, B. L. What do we know about adult mortality and data quality in Peru? Mortality coverage levels and trends from recent decades. Papeles de Población, v. 16, n. 63, p. 219-241, 2010. 
QUEIROZ, B. L.; FREIRE, F. H. M. A.; GONZAGA, M. R.; LIMA E. D. Completeness of death-count coverage and adult mortality $\left({ }_{45} q_{15}\right)$ for Brazilian states from 1980 to 2010. Revista Brasileira de Epidemiologia, v. 20, supl. 1, p. 21-33, 2017.

SCHMERTMANN, C. P.; GONZAGA, M. Bayesian estimation of age-specific mortality and life expectancy for small areas with defective vital records. Demography, v. 55, n. 4, p. 1363-1388, 2018.

SURINAME. Ministry of Internal Affairs. Centraal Bureau voor Burgerzaken (CBB). Demografische Data Suriname 2003 en 2004, Augustus 2006.

SURINAME. Ministry of Internal Affairs. Centraal Bureau voor Burgerzaken (CBB). Demografische Data Suriname 2005, Maart 2007.

SURINAME. Ministry of Internal Affairs. Centraal Bureau voor Burgerzaken (CBB). Demografische Data Suriname 2006 en 2007, November 2008.

SURINAME. Ministry of Internal Affairs. Centraal Bureau voor Burgerzaken (CBB). Demografische Data Suriname 2008 en 2009, November 2010.

SURINAME. Ministry of Internal Affairs. Centraal Bureau voor Burgerzaken (CBB). Demografische Data Suriname 2010 en 2011, December 2012.

SURINAME. Ministry of Internal Affairs. Centraal Bureau voor Burgerzaken (CBB). Demografische Data Suriname 2012, November 2013.

UNITED NATIONS. Manual X: Indirect techniques for demographic estimation. New York: United Nations, Department of Economic and Social Affairs, 1983. Available in: 〈http://www.un.org/ esa/population/publications/Manual_X/Manual_X.htm〉.

WANG, H. et al. Global, regional, and national life expectancy, all-cause mortality, and causespecific mortality for 249 causes of death, 1980-2015: a systematic analysis for the global burden of disease study 2015. Lancet. n. 388, p. 1459-544, 2016.

ZLOTNIK, H. Population growth and international migration. In: MASSEY, D.; TAYLOR, J.E. (ed.). International migration: prospects and policies in a global market. International Studies in Demography, IUSSP, Oxford University Press, 2004. p. 15-34.

\title{
About the authors
}

Andrea Fernand Jubithana holds a Ph.D in Demography. She is a Lecturer and Researcher at the Faculty of Social Sciences (FMijW) at the Anton de Kom Universiteit van Suriname (AdeKUS).

Bernardo Lanza Queiroz is Associate Professor at the Department of Demography and a researcher at Cedeplar at the Universidade Federal de Minas Gerais (UFMG).

\section{Contact address}

\author{
Andrea Fernand Jubithana \\ Universiteits campus Leysweg, 86 \\ POB: 9212 - Paramaribo, Suriname \\ Bernardo Lanza Queiroz \\ Faculdade de Ciências Econômicas - Face/UFMG \\ Av. Antônio Carlos, 6627, Pampulha \\ 31270-901 - Belo Horizonte-MG, Brazil
}




\section{Resumo}

Qualidade dos registros de óbitos e estimativas de mortalidade adulta no Suriname e regiões

O Instituto de Estatística do Suriname assume que os dados de mortalidade no país são de boa qualidade e não realiza nenhum teste antes de produzir estimativas da tabela de vida. No entanto, a falta de qualidade dos dados é uma preocupação nas áreas menos desenvolvidas do mundo. 0 objetivo principal deste artigo é avaliar a qualidade do registro de óbitos no país e suas principais regiões, entre 2004 e 2012, e produzir estimativas de mortalidade adulta por sexo. Utilizamos dados populacionais, por idade e sexo, dos últimos censos e contagem de mortes do Centro Nacional de Estatística. Para realizar a análise, foram empregados métodos demográficos tradicionais. Concluímos que a qualidade do registro de óbitos no Suriname e em suas regiões centrais é razoável. Também mostramos que os dados de registro da população podem ser considerados bons. Os resultados revelam uma pequena diferença no grau de cobertura do registro de óbitos para homens e mulheres e que, para as regiões, a escolha do método tem implicações nos resultados. Em suma, a qualidade dos dados no Suriname é melhor do que na maioria dos países da região, mas há diferenças regionais consideráveis, como observado em outros lugares.

Palavras-chave: Suriname. Registro vital. Qualidade dos dados. Estimativas de mortalidade. Método de distribuição de mortes.

\section{Resumen}

Calidad de los recuentos de registros de muerte y mortadlidad adulta en Surinam y sus principales regiones

La oficina de estadísticas de Surinam supone que los datos de mortalidad en el país son de buena calidad y no hace ninguna prueba antes de producir estimaciones de la tabla de vida. Sin embargo, la falta de calidad de datos es una preocupación en las zonas menos desarrolladas del mundo. El objetivo principal de este artículo es evaluar la calidad del registro de recuentos de defunciones en el país y sus principales regiones entre 2004 y 2012 y producir estimaciones de mortalidad de adultos por sexo. Utilizamos datos de la población, por edad y sexo, de los últimos censos y recuentos de muertes de la oficina de Estadística. Utilizamos métodos demográficos tradicionales para realizar el análisis. Encontramos que la calidad del registro del recuento de defunciones en Surinam y sus regiones centrales es de razonable a buena. Asimismo, hallamos que los datos de población pueden considerarse también buenos. Los resultados revelan una pequeña diferencia en la integridad para hombres y mujeres y que para la población subnacional la elección del método tiene implicaciones en los resultados. En resumen, la calidad de los datos en Surinam es mejor que la de la mayoría de los países de la región, pero existen diferencias regionales considerables, como también se observa en otros lugares.

Palabras clave: Surinam. Registros vitales. Calidad de datos. Estimaciones de mortalidad. Métodos de distribución de muertes. 